\title{
Identification of Compounds in Elaeis guineensis Fruits using GC-MS
}

\section{Emmanuel Eimiomodebheki Odion ${ }^{1}$, Rachel Ogheneovo Ogboru ${ }^{2}$ and Mike Oshor Ighene ${ }^{1}$}

\author{
${ }^{1}$ Department of Pharmaceutical Chemistry, Faculty of Pharmacy, University of Benin, Benin City, Nigeria \\ ${ }^{2}$ Research Co-ordinating Unit, Forestry Research Institute of Nigeria, Ibadan, Oyo State, Nigeria
}

(Received: March 14, 2020; Accepted: November 23, 2020; Published (web): December 10, 2020)

\begin{abstract}
The aim of this study was to identify the chemical constituents of Elaeis guineensis (EG) using GCMS. EG fruits were purchased from a local market in Edo state and was identified, cleaned, boiled and extracted. The resultant crude extract was strained through filter paper and partitioned into n-hexane, dichloromethane and ethyl acetate before subjected to GC-MS analysis. Eighty-two (82) compounds were identified and the major components are hexadecanoic acid, methyl ester (10.53\%), oleic acid (25.92\%). n-hexadecanoic acid (31.41\%), cis-vaccenic acid $(22.82 \%)$ and octadecanoic acid $(13.16 \%)$. Plants fatty acids are important for growth and defence mechanism against pathogen, possess antimicrobial action, implicated in pathway elucidation and stimulation of resistance mechanism in plants. Long chain fatty acids exert their effect on membrane phospholipids by modifying its composition and potentially interfering with synthesis of lipid signalling molecules. Identification of EG fruits have provided an idea of its chemical composition of the extract of E. guineensis.
\end{abstract}

Key words: Elaeis guineensis fruit, fatty acid, GC-MS and vaccenic acid.

\section{INTRODUCTION}

Elaeis guineensis (EG) known as African oil palm, is a perennial monocot plant of the family Arecaceae $^{1}$ and originate from the Gulf of Guinea in tropical rain forest of Africa. ${ }^{2}$ It was first introduced to other countries in 15th century by the Portuguese explorer. ${ }^{3}$ The palm fruit is an orange red drupe which produces $45-55 \%$ oil, from the fleshy mesocarp by mechanical milling or by traditional method. The colour of the oil palm ranges from light yellow to orange-red with melting point of $25^{\circ} \mathrm{C} .^{1,4}$

It is used ethno-medicinally for the management and treatment of joint pain, headache and to enhance libido. It is used as diuretic, in the promotion of wound healing and to promote the expression of breast milk during lactation. ${ }^{5,6}$ It is also used orally as poison antidote and externally with many other herbs

Correspondence to: Emmanuel Eimiomodebheki Odion E-mail: emmanuel.odion@uniben.edu; Tel. no.: +2349076629635

Dhaka Univ. J. Pharm. Sci. 19(2): 153-159, 2020 (December) DOI: https://doi.org/10.3329/dujps.v19i2.50631 as lotion for skin diseases. Basically, palm oil is use for cooking, soap making, creams and cosmetics production. ${ }^{5}$

Gas chromatography (GC) is a widely applied technique that plays fundamental role in detection of the components and their proportions in a mixture. ${ }^{7}$

When it is couple to a mass spectrometer (MS), it has the advantage of simultaneously determining the molecular weight of each component detected. The disadvantage with this method include interference and overlap from co-extracted sample, can be reduced or overcome by the selection of appropriate fragment ions and analytical columns. ${ }^{8}$

Literature search have not shown the profiling of EG fruit extract for its chemical constituent. Thus the need for the profiling of the fruit extract of EG, to obtain an idea of the compounds that responsible for some of its activities. 


\section{MATERIALS AND METHODS}

Plant collection and identification. The fruit of EG was purchased at Oba market, Oredo Local Government Area of Edo State, in September 2019. It was identified at the Department of Plant Biology and Biotechnology, University of Benin, by Dr. Akinnibosun H.A. and voucher specimen was deposited with a herbarium number of UBH-E444.

Preparation and extraction of the fruit. The fruits of EG fruits were hand-picked and washed with distilled water to remove dirt and other possible contaminants. About $1.5 \mathrm{~kg}$ of EG fruit was added to a 2 litres of boiling water at $100{ }^{\circ} \mathrm{C}$ and allowed to boil for about 45 minute, thereafter, the water was decanted and the boiled EG fruit was transferred into a mortar and a pestle was used to triturated before adding about 1litre of warm distilled water. Trituration was continued until the fleshy mesocarp was separated. About 500 millilitre of deionized water was added to the content and stirred continuously until all the fleshy components were completely removed from the seed to obtain the extract. The palm kernel seeds and chaft were filtered out from the crude extract. The content crude extract was further concentrated by passing it through the filter paper to remove the water content. The endocarp and fibrous mesocarp were discarded. The resultant crude extract was strained through a filter paper and the residue was weighed with the aid of a weighing scale and stored in a beaker in a refrigerator.

Partitioning. Fractionation was done by weighing about $189 \mathrm{~g}$ of the concentrated crude extract into a beaker and dissolve with $100 \mathrm{ml}$ of methanol before $250 \mathrm{ml}$ of water. These were vigorously stirred before transferring to a separating funnel. About $200 \mathrm{ml}$ of $\mathrm{n}$-hexane was added to the mixture and rocked gently to prevent the formation of emulsion and the content was opened occasionally to expel out gases formed in the separating funnel. The mixture was left on standing for about $1 \mathrm{hr}$ before decanting the $\mathrm{n}$-hexane fraction. Similar volume of $\mathrm{n}$ hexane was added until the extract became colourless. Similar procedure was carried out by using dichloromethane and ethyl acetate solvents. Each of the samples so obtained were labelled appropriately and subjected to Gas chromatography mass spectroscopy (GC-MS) analysis

GC-MS condition. Gas chromatography- mass spectrometry (GC-MS) analyses of the fractions were performed on QP 2010 SE Shimadzu Japan. Separation was achieved on a restek Rt x $5 \mathrm{~ms}$ column (0.32 film thickness). The GC operating conditions were as follows. Temperature holds at $90^{\circ} \mathrm{C}$ for 1 min, increases from $90^{\circ} \mathrm{C}$ to $150^{\circ} \mathrm{C}$ at a rate of $13 \mathrm{~min}$ and with final isothermal hold at $300^{\circ} \mathrm{C}$ at a rate of 13 min and with final isothermal hold at $300^{\circ} \mathrm{C}$ for 2 min. helium was used as the carrier gas. The sample was injected in the split mode with the injector temperature at $250^{\circ} \mathrm{C}$. The mass spectrometer was operated in the electron impact mode at $70 \mathrm{eV}$ ionization energy and scanned from 45 to 700 Dalton. Data were acquired and processed using ChemStation software. Compounds were identified by comparing their base peak and two other major peaks (selected ion monitoring mode) from the fragmentation pattern for each compound and these were compared with data from National Institute of Standard Technology (NIST) library.

\section{RESULTS AND DISCUSSION}

The retention time of a compound could be used as a means of qualitative identification, but that could mean matching with standards. ${ }^{9}$ This could lead to overlap in the retention time in some case, which is surmounted by using MS as the detector. GC-MS analysis for compounds present in EG, was done in n-hexane, dichloromethane and ethyl acetate fractions. The result showed that twenty-nine (29) compounds were identified from ethyl acetate fraction, twenty-eight (28) from n-hexane fraction and twenty-five (25) from dichloromethane fraction. The peaks were individually identified by comparing the detected mass-to-charge $(\mathrm{m} / \mathrm{z})$ ratios against a standard mass spectrum from National Institute of Standards and Technologies 11 (NIST 11) Library with peaks similarity. This was aided by 
identification of the molecular ion $\left(\mathrm{M}^{+}\right)$, base peak and two confirmatory ions.

Figures 1, 2 and 3 show the peaks from the chromatogram of the fractions (ethyl acetate, dichloromethane and n-hexane) of EG fruits. These peaks were identified by passing them through a mass spectrometer and the fragmentation pattern for each peak was matched with NIST library using selected ion mentoring mode.

Table 1 shows the level of different compounds from ethyl acetate fraction of $\mathrm{EG}$, including hexadecanoic acid, methyl ester (10.53\%), oleic acid (14.29\%), 9-octadecenoic acid, methyl ester (E) $(9.46 \%)$ and $n$-hexadecanoic acid (18.75\%) which were observed to be high. High level of fatty acids and esters in EG is in agreement with previous study. ${ }^{10}$ The presence of hexadecanoic acid is an important growth and defence mechanism against pathogen in EG. ${ }^{11}$ Fatty acids have been shown to possess antimicrobial action; ${ }^{12}$ while others have been implicated in pathway elucidation ${ }^{13}$ and stimulation of resistance mechanism in plants. ${ }^{14}$ Biologically active long chain fatty acids exert their effect on membrane phospholipids by modifying its composition and potentially replacing or interfering with the synthesis of phospholipid derived lipid signalling molecules, including endocannabinoids. ${ }^{15}$

The level of n-hexadecanoic acid (18.71\%), 9octadecenoic acid, methyl ester, (E)-(7.83\%) and oleic acid (25.92\%) in dichloromethane fraction in EG is high (Table 2). These sets of compound were also identified in the ethanol fraction. High level of hexadecanoic acid has been identified in root samples of oil palm and proven to play a defence role mechanisms. ${ }^{16}$ Various pharmacological activities of EG constituents have been reported such as unsaturated fatty acid and linolenic acid possess antimicrobial, anti-inflammatory, antioxidant, hypocholesterolemic, cancer preventive, hepatoprotective, antiarthritic and antihistimic. ${ }^{17}$

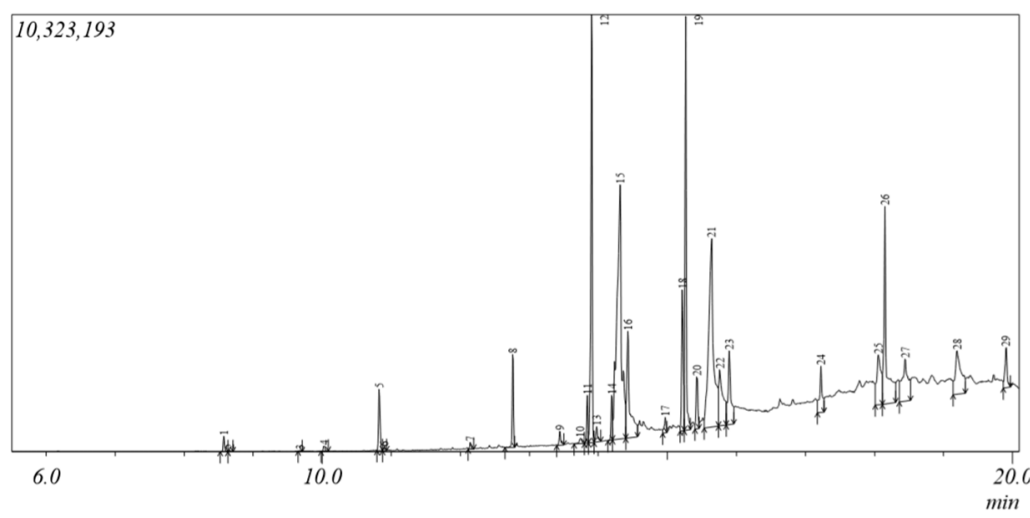

Figure 1. Peaks from the chromatogram obtained from the ethyl acetate fraction of EG fruits.

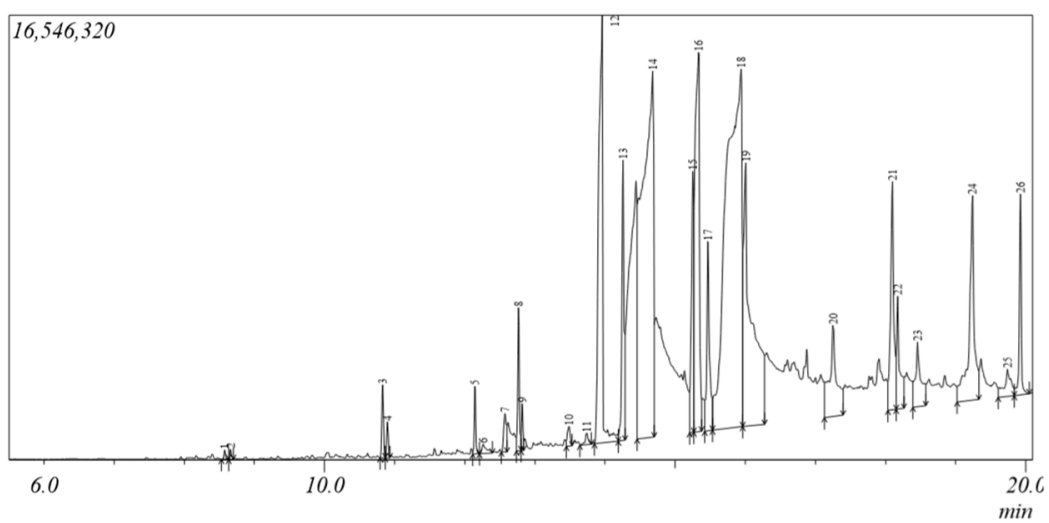

Figure 2. Peaks from the chromatogram obtained from the dichloromethane fraction of EG fruits. 


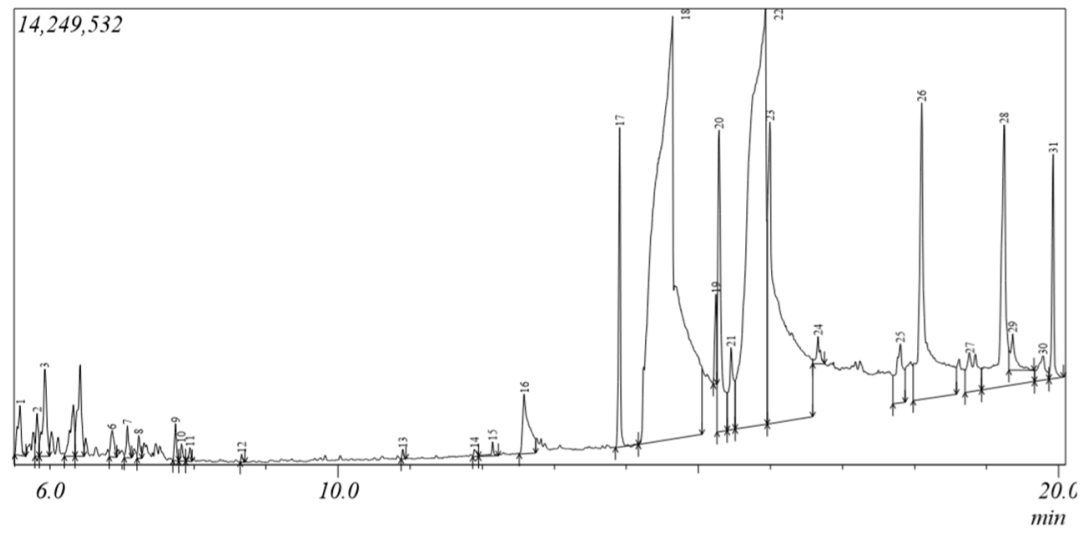

Figure 3. Peaks from the chromatogram obtained from the n-hexane fraction of EG fruits.

Table 1. Compounds that were identified from the ethyl acetate fraction of EG using GC-MS analysis.

\begin{tabular}{|c|c|c|c|c|c|c|c|c|}
\hline $\mathrm{S} / \mathrm{N}$ & Compounds & $\%$ Area & $\mathrm{RT}(\mathrm{s})$ & CAS & MW & Class & $\begin{array}{l}\text { Identifica- } \\
\text { tion ion }\end{array}$ & $\begin{array}{l}\text { Confirma- } \\
\text { tion ion }\end{array}$ \\
\hline 1 & 9-Octadecene, (E)- & 0.38 & 8.63 & $7206-25-9$ & 252 & Alkene & 55 & 6983 \\
\hline 2 & Nonane, 3,7-dimethyl- & 0.04 & 8.71 & $17302-32-8$ & 156 & Alkane & 57 & 7185 \\
\hline 3 & 2-Bromononane & 0.02 & 9.71 & $2216-35-5$ & 206 & Organo-halide & 43 & 5771 \\
\hline 4 & Phenol, 2,4-bis(1,1-dimethylethyl)- & 0.14 & 10.09 & $96-76-4$ & 206 & Alcohol & 191 & 57206 \\
\hline 5 & 1-Hexadecanol & 1.42 & 10.88 & $36653-82-4$ & 242 & Alcohol & 55 & 6983 \\
\hline 6 & Tetratetracontane & 0.08 & 10.93 & $7098-22-8$ & 618 & Alkane & 57 & 4371 \\
\hline 7 & Cyclopentanetridecanoic acid, methyl ester & 0.16 & 12.19 & $24828-61-3$ & 296 & Ester & 74 & 5587 \\
\hline 8 & 1-Nonadecene & 2.14 & 12.79 & $18435-45-5$ & 266 & Alkene & 59 & 8397 \\
\hline 9 & Phthalic acid, butyl undecyl ester & 0.38 & 13.50 & $0-00-0$ & 376 & Ester & 149 & 5771 \\
\hline 10 & 7-Hexadecenal, (Z)- & 0.23 & 13.80 & $56797-40-1$ & 238 & Aldehyde & 57 & 7183 \\
\hline 11 & Phthalic acid, isobutyl undecyl ester & 1.00 & 13.86 & $0-00-0$ & 376 & Ester & 149 & 57223 \\
\hline 12 & Hexadecanoic acid, methyl ester & 10.53 & 13.94 & $112-39-0$ & 270 & Ester & 74 & 5587 \\
\hline 13 & Phthalic acid, butyl undecyl ester & 0.48 & 14.03 & $: 0-00-0$ & 376 & Ester & 149 & 57223 \\
\hline 14 & $\begin{array}{l}\text { Cyclohexanecarboxaldehyde, 6-methyl-3- } \\
\text { (1-methylethyl)-2-oxo- }\end{array}$ & 1.03 & 14.21 & $28745-06-4$ & 182 & Aldehyde & 140 & 5567 \\
\hline 15 & n-Hexadecanoic acid & 18.75 & 14.40 & $57-10-3$ & 256 & Alkanoic acid & 73 & 5560 \\
\hline 16 & n-Nonadecanol-1 & 4.87 & 14.57 & $1454-84-8$ & 284 & Alcohol & 57 & 8397 \\
\hline 17 & Phthalic acid, butyl undecyl ester & 0.44 & 14.99 & $0-00-0$ & 376 & Ester & 149 & 57104 \\
\hline 18 & 9,12-Octadecadienoic acid, methyl ester & 3.59 & 15.24 & $2462-85-3$ & 294 & Ester & 67 & 5581 \\
\hline 19 & 9-Octadecenoic acid, methyl ester, (E)- & 9.46 & 15.33 & $1937-62-8$ & 296 & Ester & 55 & 6974 \\
\hline 20 & Heptadecanoic acid, 10-methyl-, methyl ester & 1.31 & 15.46 & $2490-25-7$ & 298 & Ester & 74 & 5587 \\
\hline 21 & Oleic Acid & 14.29 & 15.74 & $112-80-1$ & 282 & Alkanoic acid & 55 & 6983 \\
\hline 22 & 9,9-Dimethoxybicyclo[3.3.1] nona-2,4-dione & 3.48 & 15.85 & 117132-08-8 & 212 & Ketone & 55 & 5768 \\
\hline 23 & n-Tetracosanol-1 & 3.31 & 15.97 & $506-51-4$ & 354 & Alcohol & 55 & 8397 \\
\hline 24 & 17-Pentatriacontene & 1.82 & 17.27 & $6971-40-0$ & 490 & Alkene & 57 & 5597 \\
\hline 25 & 7-Hexadecenal, (Z)- & 3.47 & 18.12 & $56797-40-1$ & 238 & Aldehyde & 57 & 5568 \\
\hline 26 & Bis-(2-ethylhexyl) phthalate & 7.79 & 18.31 & $117-81-7$ & 390 & Ester & 149 & 57167 \\
\hline 27 & 17-Pentatriacontene & 3.97 & 18.53 & $6971-40-0$ & 490 & Alkane & 57 & 5571 \\
\hline 28 & 7-Hexadecenal, (Z)- & 4.03 & 19.32 & $56797-40-1$ & 238 & Aldehyde & 55 & 5769 \\
\hline 29 & $\begin{array}{l}\text { 2,2,4-Trimethyl-3-(3,8,12,16-tetramethyl- } \\
\text { heptadeca }\end{array}$ & 1.44 & 19.97 & $0-00-0$ & 428 & Alkane & 69 & 5781 \\
\hline
\end{tabular}


Table 2. Compounds that were identified from the Dichloromethane fractions of EG using GC-MS analysis.

\begin{tabular}{|c|c|c|c|c|c|c|c|c|}
\hline $\mathrm{S} / \mathrm{N}$ & Compounds & $\begin{array}{l}\% \\
\text { Area }\end{array}$ & $\mathrm{RT}(\mathrm{s})$ & CAS & MW & Class & $\begin{array}{l}\text { Identifica- } \\
\text { tion ion }\end{array}$ & $\begin{array}{l}\text { Confirma- } \\
\text { tion ion }\end{array}$ \\
\hline 1 & 9-Octadecene, (E)- & 0.08 & 8.63 & $7206-25-9$ & 252 & Alkene & 55 & 6983 \\
\hline 2 & Hexadecane & 0.08 & 8.70 & $544-76-3$ & 226 & Alkane & 57 & 7185 \\
\hline 3 & 9-Eicosene, (E)- & 0.52 & 10.87 & $74685-29-3$ & 280 & Alkene & 55 & 8397 \\
\hline 4 & Hexadecane & 0.24 & 10.93 & $629-94-7$ & 296 & Alkane & 57 & 7185 \\
\hline 5 & Methyl tetradecanoate & 0.52 & 12.21 & $124-10-7$ & 242 & Ester & 74 & 5587 \\
\hline 6 & Isolongifolan-7-ol & 0.19 & 12.39 & $0-00-0$ & 222 & Alcohol & 207 & $57 \quad 222$ \\
\hline 7 & Tetradecanoic acid & 0.51 & 12.60 & $544-63-8$ & 228 & Acid & 73 & 5560 \\
\hline 8 & 1-Nonadecene & 1.17 & 12.80 & $18435-45-5$ & 266 & Alkane & 55 & 8397 \\
\hline 9 & Nonadecane & 0.33 & 12.84 & $629-92-5$ & 268 & Alkane & 57 & 7185 \\
\hline 10 & Oxirane, hexadecyl- & 0.25 & 13.53 & $7390-81-0$ & 268 & Heterocycle & 83 & 5561 \\
\hline 11 & 7-Hexadecenoic acid, methyl ester, (Z)- & 0.15 & 13.81 & $56875-67-3$ & 268 & Ester & 55 & 6983 \\
\hline 12 & Hexadecanoic acid, methyl ester & 7.95 & 14.19 & $112-39-0$ & 270 & Ester & 74 & 5587 \\
\hline 13 & $\begin{array}{l}\text { 1,2-Benzenedicarboxylic acid, butyl 2- } \\
\text { ethylhexyl ester }\end{array}$ & 2.99 & 14.28 & $85-69-8$ & 334 & Ester & 149 & 55104 \\
\hline 14 & n-Hexadecanoic acid & 18.71 & 14.70 & $57-10-3$ & 256 & Acid & 73 & 5560 \\
\hline 15 & 9,12-Octadecadienoic acid, methyl ester & 2.91 & 15.27 & $2462-85-3$ & 294 & Ester & 67 & 5581 \\
\hline 16 & 9-Octadecenoic acid, methyl ester, (E)- & 7.83 & 15.38 & $1937-62-8$ & 296 & Ester & 55 & 6997 \\
\hline 17 & Methyl stearate & 2.41 & 15.53 & $112-61-8$ & 298 & Ester & 74 & 5587 \\
\hline 18 & Oleic Acid & 25.92 & 15.97 & $112-80-1$ & 282 & Acid & 55 & 6997 \\
\hline 19 & Octadecanoic acid & 9.85 & 16.28 & $57-11-4$ & 284 & Acid & 55 & 73129 \\
\hline 20 & $\mathrm{n}$-Tetracosanol-1 & 3.00 & 17.39 & $506-51-4$ & 354 & Alcohol & 55 & 8397 \\
\hline 21 & $\begin{array}{l}\text { Hexadecanoic acid, 2-hydroxy-1- } \\
\text { (hydroxymethyl)ethyl ester }\end{array}$ & 3.48 & 18.15 & $23470-00-0$ & 330 & Ester & 98 & 5774 \\
\hline 22 & Bis(tridecyl) phthalate & 1.65 & 18.27 & $119-06-2$ & 530 & Aromatic & 149 & 57167 \\
\hline 23 & 17-Pentatriacontene & 1.60 & 18.58 & $6971-40-0$ & 490 & Alkene & 55 & 8397 \\
\hline 24 & Oleoyl chloride & 4.82 & 19.33 & $112-77-6$ & 300 & Organo-halide & 55 & 6981 \\
\hline 25 & 17-Pentatriacontene & 0.82 & 19.83 & $111-02-4$ & 410 & Alkene & 69 & 8195 \\
\hline
\end{tabular}

Table 3. Compounds that were identified from the n-hexane fraction of EG using GC-MS analysis.

\begin{tabular}{|c|c|c|c|c|c|c|c|c|}
\hline $\begin{array}{l}\mathrm{S} / \\
\mathrm{N}\end{array}$ & Compounds & $\begin{array}{l}\% \\
\text { Area } \\
\end{array}$ & $\mathrm{RT}(\mathrm{s})$ & CAS & MW & Class & $\begin{array}{l}\text { Identifica- } \\
\text { tion ion }\end{array}$ & $\begin{array}{l}\text { Confir- } \\
\text { mation ion }\end{array}$ \\
\hline 1 & Benzene-1,2,4,5-tetramethyl- & 0.57 & 5.67 & $95-93-2$ & 134 & Aromatic & 119 & 91134 \\
\hline 2 & Benzene, 1-methyl-2-(2-propenyl)- & 0.33 & 5.850 & $1587-04-8$ & 132 & Aromatic & 117 & 91132 \\
\hline 3 & 2,4-Dimethylstyrene & 1.13 & 5.992 & $2234-20-0$ & 132 & Alkane & 117 & 91132 \\
\hline 4 & Benzene, 1-methyl-4-(1-methyl-2-propenyl)- & 0.72 & 6.350 & $97664-18-1$ & 146 & Aromatic & 131 & 91146 \\
\hline 5 & 2-Naphthalenol, 1,2-dihydro-, acetate & 1.18 & 6.475 & $132316-80-4$ & 188 & Aromatic & 128 & 132146 \\
\hline 6 & 2-Ethyl-2,3-dihydro-1H-indene & 0.30 & 6.925 & $56147-63-8$ & 146 & Aromatic & 117 & 131146 \\
\hline 7 & 1H-Indene, 2,3-dihydro-4,7-dimethyl- & 0.26 & 7.133 & $6682-71-9$ & 146 & Aromatic & 131 & 115146 \\
\hline 8 & Naphthalene, 2-methyl- & 0.24 & 7.792 & $91-57-6$ & 142 & Aromatic & 142 & 71115 \\
\hline 9 & 2,4-Decadienal, (E,E)- & 0.14 & 7.883 & $25152-84-5$ & 152 & Aldehyde & 81 & 5567 \\
\hline 10 & Naphthalene, 1-methyl- & 0.11 & 7.975 & $90-12-0$ & 142 & Aromatic & 142 & 115139 \\
\hline 11 & Hexadecane & 0.04 & 8.708 & $544-76-3$ & 226 & Alkane & 57 & 7185 \\
\hline 12 & 2-methyltetracosane & 0.05 & 10.942 & $0-00-0$ & 352 & Alkane & 57 & 4371 \\
\hline 13 & Cyclopentanetridecanoic acid, methyl ester & 0.12 & 12.225 & $24828-61-3$ & 296 & Ester & 74 & 5587 \\
\hline 14 & Tetradecanoic acid & 1.23 & 12.742 & $544-63-8$ & 228 & Acid & 73 & 5560 \\
\hline
\end{tabular}




\begin{tabular}{|c|c|c|c|c|c|c|c|c|}
\hline 15 & Hexadecanoic acid, methyl ester & 2.06 & 14.167 & $112-39-0$ & 270 & Ester & 74 & 5587 \\
\hline 16 & n-Hexadecanoic acid & 31.41 & 15.050 & $57-10-3$ & 256 & Acid & 60 & 5573 \\
\hline 17 & 9,12-Octadecadienoic acid (Z,Z)- & 0.57 & 15.258 & $60-33-3$ & 280 & Acid & 67 & 5581 \\
\hline 18 & 9-Octadecenoic acid (Z)-, methyl ester & 3.19 & 15.400 & $112-62-9$ & 296 & Ester & 55 & 6983 \\
\hline 19 & Methyl 9-methyltetradecanoate & 1.22 & 15.508 & $213617-69-7$ & 256 & Ester & 74 & 5587 \\
\hline 20 & cis-Vaccenic acid & 22.82 & 15.958 & $506-17-2$ & 282 & Acid & 55 & 6983 \\
\hline 21 & Octadecanoic acid & 13.16 & 16.583 & $57-11-4$ & 284 & Acid & 55 & 5773 \\
\hline 22 & Cyclopentadecanone, 2-hydroxy & 0.28 & 16.750 & $4727-18-8$ & 240 & Ketone & 55 & 6983 \\
\hline 23 & $\begin{array}{l}\text { Hexadecanoic acid, 2-hydroxy-1- } \\
\text { (hydroxymethyl)ethyl ester }\end{array}$ & 7.00 & 18.583 & $23470-00-0$ & 330 & Ester & 98 & $57 \quad 74$ \\
\hline 24 & 9,19-Cyclolanostan-3-ol, acetate, (3.beta.)- & 1.35 & 18.933 & $4575-74-0$ & 270 & Ester & 69 & 55159 \\
\hline 25 & Oleoyl chloride & 6.17 & 19.667 & $112-77-6$ & 300 & $\begin{array}{l}\text { Organo- } \\
\text { halide }\end{array}$ & 55 & 6781 \\
\hline 26 & Methyl 12-oxo-9-dodecenoate & 0.59 & 19.658 & $22418-58-2$ & 226 & Ester & 55 & 6998 \\
\hline 27 & 7-Hexadecenal, (Z)- & 0.58 & 19.87 & $56797-40-1$ & 238 & Aldehyde & 55 & 6983 \\
\hline 28 & Squalene & 1.59 & 20.07 & $111-02-4$ & 410 & Alkene & 69 & 8195 \\
\hline
\end{tabular}

In the $n$-hexane fraction (Table 3), nhexadecanoic acid (31.41\%), cis-vaccenic acid $(22.82 \%)$ or 11 -octadecenoic acid and octadecanoic acid (13.16\%), hexadecanoic acid, 2-hydroxy-1(hydroxymethyl) ethyl ester (7.00\%) and oleoyl chloride $(6.17 \%)$ were identified. Vaccenic acid potentiate complications seen in dyslipidemia, fatty liver disease, and low-grade inflammation. ${ }^{18}$ It has been proposed that the lipid-lowering and antiinflammatory effects of vaccenic acid may be partially associated with its ability to ligand activate PPAR $\gamma$-regulated pathways, by acting directly in the intestine and adipose tissue. ${ }^{14}$ Furthermore, given the bioactive properties of vaccenic acid to favourably modulate whole body energy metabolism and lowgrade inflammation. ${ }^{14}$

Esters with methyl attached to the fatty acid are mostly grouped as fatty acid methyl ester and has shown susceptibility to isolates of Paracoccidioides $(\mathrm{MIC}=15.6 \mu \mathrm{g} / \mathrm{ml})$. Antimicrobial activity have been reported for oil with stearic, palmitic, oleic, linoleic and linolenic acids components, ${ }^{19}$ this could be attributed to the presence of fatty acids. ${ }^{12}$

\section{CONCLUSION}

The use of GC-MS analysis in profiling EG fruit for its chemical content is highly revealing, because it gave a quick opportunity for the various molecular weights of different compounds present in the fractions of EG extract to be identified. From the parent molecular ions, the approximate molecular structure of the different compounds identified was obtained. Profiling of EG have provided an idea of its chemical composition which include long and short chain fatty acids, alkane, alkene, alcohols, aldehyde and esters. These compounds are known to possess different pharmacological activity both in the plant and animals.

\section{ACKNOWLEDGEMENT}

We acknowledge Mr. Ben of Bob global Resources Limited, Abuja for running the GC-MS.

Competing interest: The authors declared no conflict of interest

Contribution to the Study. This work is an undergraduate project work for Pharm (Dr.) Mike Oshor Ighene. It was supervised Dr Emmanuel E. Odion and Co-supervised by Rachel O. Ogboru. The idea of the work was conceived by Emmanuel Odion and Rachel Ogboru, Mike conducted the experiment under the guidance of Emmanuel Odion, data were analyzed by Emmanuel and Rachel. Write up was done by Emmanuel and Rachel. 


\section{REFERENCES}

1. Hartley, C.W.S., 2000. The Oil Palm. 3rd Edition, Longman Press London and New York, p. 806.

2. Naher, L., Yusuf, U.K., Ismail, A., Tan, S.G. and Mondal, M.M.A. 2013. Ecological status of Ganoderma and basal stem root disease of oil palms (Elaeis guineensis Jacq.). Australian J. Crops Sci. 7, 1723-1727.

3. Corley, R.H.V. 1976. The Genus Elaeis. In: Oil Palm Research (Corley, R.H.V., Hardon, J. J. and Wood, B. J. Eds.), Elsevier Scientific Publisher Amsterdam, Netherlands. p. 532 .

4. Ekwenye, U.N. and Ijeomah, C.A. 2005. Antimicrobial effects of palm kernel oil and palm oil. King Mongkut's Inst. Tech. Ladk. Sci. J. 5, 502-505.

5. vin, T.T. 1985. Wound healing. Arch. Emerg. Med. 2, 3-10.

6. Sasidharan, S., Sharmini, R., Vijayarathna, S., Yoga Latha, L., Vijenthi R, Amala R. and Amutha S. 2009. Antioxidant and hepatoprotective activity of methanolic extracts of Elaeis guineensis Jacq leaf. Pharmacol. Online. 3, 84-90.

7. Alder, L., Greulich, K., Kempe, G. and Vieth, B. 2006. Residue analysis of 500 high priority pesticides: better by GC-MS or LC-MS/MS?. Mass Spectrum Rev. 25, 838-865.

8. Hernando, M.D., Aguera, A., Fernandez-Alba, A.R., Piedraa L. and Contrerasb, M. 2001. Gas chromatographic determination of pesticides in vegetable samples by sequential positive and negative chemical ionization and tandem mass spectrometric fragmentation using an ion trap analyser. Anal. 126, 46-51.

9. Chauhan, A., Goyal, M.K. and Chauhan, P. 2014. GC-MS technique and its analytical applications in science and technology. J. Anal. Bioanal. Tech. 5, 222.

10. Kamatou, G.P.P. and Viljoen A.M. 2017. Comparison of fatty acid methyl esters of palm and palmist oils determined by GCxGC-ToF-MS and GC-MS/FID. South Afr. J. Bot. 112, 483-488
11. Rozali, N.L., Yarmo, M.A., Idris A.S., Kushairi, A. and Ramli, U.S. 2017. Metabolomics differentiation of oil palm (Elaeis guineensis Jacq.) spear leaf with contrasting susceptibility to Ganoderma boninense. Plant Omics J. 10, 45-52.

12. Desbois, A.P. and Smith, V.J. 2009. Antibacterial free fatty acids: activities, mechanisms of action and biotechnological potential. Appl. Microbiol. Biotech. 85, 1629-1642.

13. Farmer, E.E., Weber, H. and Vollenweider, S. 1998. Fatty acid signalling in Arabidopsis. Planta. 206, 167-174.

14. Jacome-Sosa, M. M., Lu, J., Wang, Y., Ruth, M.R., Wright, D.C., Reaney, M. J., Shen, J., Field, C.J., Vine, D. F. and Proctor, S. D. 2010. Increased hypolipidemic benefits of cis9, trans-11 conjugated linoleic acid in combination with trans-11 vaccenic acid in a rodent model of the metabolic syndrome, the JCR:LA-cp rat. Nutr. Metab.7, 60.

15. Fernandis, A. Z. and Wenk, M. R. 2007. Membrane lipids as signaling molecules. Curr. Opin. Lip. 18, 121-128.

16. Nusaibah, S.A., Akmar, S.N. A., Idris, A.S., Sariah, M. and Mohamad, P. Z. 2016. Involvement of metabolites in early defence mechanism of oil palm (Elaeis guineensis Jacq.) against Ganoderma disease. Plant Physiol. Bioch. 109, 156165.

17. Sahreen, S, Khan, M.R. and Khan, R.A. 2010. Evaluation of antioxidant activities of various solvent extracts of Carissa opaca fruits. Food Chem.122, 1205-1211.

18. Wang, Y., Lu, J., Ruth, M.R., Goruk, S.D., Reaney, M.J., Glimm, D.R., Vine, D.F., Field, C.J. and Proctor, S.D. 2008. Trans-11 vaccenic acid dietary supplementation induces hypolipidemic effects in JCR:LA-cp rats. J. Nutr. 138, 2117 2122.

19. Ogawa, J., Kishino, S., Ando, A., and Satoshi Sugimoto, S. 2005. Review: production of conjugated fatty acids by lactic acid bacteria. J. Biosci. Bioeng. 100, 355-364. 